4. Барихин А.Б. Большая юридическая энциклопедия, Москва : Книжный мир, 2010.960 с.

5. Словарь бизнес-терминов / сост.: Г. Бетс, Б. Брейндли, С. Уильямс и др. ; общ. ред.: И.М. Осадчая. Москва : Книжный мир, 2017. 1014 с.

6. Паліюк В.П. Відшкодування моральної (немайнової) шкоди : монографія. 2-ге вид., випр. і доп. Київ : Право, 2000. 272 с.

7. Конституція України від 28 червня 1996 р. № 254к/96-ВР.

8. Цивільний кодекс України від 16 січня 2003 р. № 435-IV.9. Закон України «Про порядок відшкодування шкоди, завданої громадянинові незаконними діями органів дізнання, досудового слідства, прокуратури і суду» від 1 грудня 1994 р. № 266/94-ВР.

9. Про зовнішньоекономічну діяльність : Закон України від 16 квітня 1991 р. № 959-XII із чинними змінами станом на 2019 p.

10. Про судову практику в справах про відшкодування моральної (немайнової) шкоди : Постанова Пленуму Верховного Суду України ; документ 0004700-95, поточна редакція 27 лютого 2009 p.

ПИНЯГА Р.О.

\author{
ТАКТИКО-КРИМІНАЛІСТИЧНЕ ЗАБЕЗПЕЧЕННЯ ПРОВЕДЕННЯ \\ ДОПИТУ НА ПОЧАТКОВОМУ ЕТАПІ РОЗСЛІДУВАННЯ КРИМІНАЛЬНИХ \\ ПРАВОПОРУШЕНЬ, ПОВ'ЯЗАНИХ ІЗ ЗАЙНЯТТЯМ ГРАЛЬНИМ БІЗНЕСОМ
}

\title{
TACTICS-FORENSIC SUPPORT OF INTERROGATION AT THE INITIAL STAGE OF INVESTIGATION OF CRIMINAL OFFENSES RELATED TO GAMBLING
}

\begin{abstract}
У статті наголошується, що, незважаючи на статус допитуваного, тип грального закладу та інші обставини, під час допиту свідків і підозрюваних з'ясовують: осіб, які організували азартні ігри, їх проводили та надавали можливість доступу до них; вид ігор, що було організовано та проведено; місце (місця) вчинення злочину; період злочинної діяльності; дані стосовно гравців; факт зв'язку грального бізнесу з учиненням інших злочинів та правопорушень; форму співучасті та роль співучасників; зв'язки організаторів азартних ігор з державними органами; заходи конспірації; характер і розмір прибутків від грального бізнесу. Залежно від категорії свідків, оцінено можливості використання суперечностей у показаннях допитуваного та iнших доказів, чинника раптовості й інших тактичних прийомів допиту. Конфліктні ситуації під час допиту підозрюваних пов'язані з тим, що допитувані зазвичай не визнають свою винуватість, перекладаючи вину на інших співучасників або наполягаючи на тому, що не усвідомлювали злочинного характеру своїх дій. 3'ясовано, що у конфліктній ситуації, що складається на момент допиту, слідчий може застосувати такі тактичні прийоми, як: роз'яснення допитуваному значення щирого зізнання і давання правдивих свідчень; виявлення мотивів давання неправдивих показань й усунення цих мотивів; переконання з допомогою логічних аргументів у недоцільності спроб давання неправдивих свідчень; максимальна деталізація і конкретизація свідчень допитуваного; пред’явлення доказів, що викривають допитуваного (починаючи із самого важливого і навпаки); повторний допит. Визначено, що, незважаючи на статус допитуваного, тип грального закладу та інші обставини, під час допиту свідків і підозрюваних з'ясовують: осіб, які організували азартні ігри, їх проводили та надавали можливість доступу до них; вид ігор, що було організовано та проведено;
\end{abstract}

(с) ПИНЯГА Р.О. - кандидат юридичних наук 
місце (місця) вчинення злочину; період злочинної діяльності; дані стосовно гравців; факт зв'язку грального бізнесу з учиненням інших злочинів та правопорушень; форму співучасті та роль співучасників; зв'язки організаторів азартних ігор з державними органами; заходи конспірації; характер і розмір прибутків від грального бізнесу.

Ключові слова: гральний бізнес, азартна гра, кримінальні правопорушення, доказування, допит, свідок, підозрюваний.

The article emphasizes that regardless of the status of the interrogated person the type of gambling establishment and other circumstances, during the interrogation of witnesses and suspects they find out: persons who organized gambling activities, conducted them and provided access to them; the type of games that were organized and conducted; place (places) of crime; period of criminal activity; data on players; the fact of connection of the gambling business with the commission of other crimes and offenses; the form of complicity and the role of accomplices; connections of gambling organizers with state bodies; conspiracy measures; the nature and amount of profits from the gambling business. Depending on the category of witnesses, the possibilities of using contradictions in the testimony of the interrogated and other evidence, the factor of suddenness and other tactics of interrogation were assessed. Conflicts during the interrogation of suspects are due to the fact that the interrogees usually do not admit their guilt, shifting the blame to other accomplices or insisting that they were not aware of the criminal nature of their actions. It was found that in a conflict situation at the time of interrogation, the investigator may use the following tactics: explaining to the interrogated the importance of sincere confession and giving truthful testimony; identification of motives for giving false testimony and elimination of these motives; belief with the help of logical arguments in the inexpediency of attempts to give false testimony; maximum detailing and concretization of the interrogated's testimony; presentation of evidence exposing the interrogated (starting from the most important and vice versa); re-interrogation. It was determined that despite the status of the interrogated person, the type of gambling establishment and other circumstances, during the interrogation of witnesses and suspects they find out: persons who organized gambling games, conducted them and provided access to them; the type of games that were organized and conducted; place (places) of crime; period of criminal activity; data on players; the fact of connection of the gambling business with the commission of other crimes and offenses; the form of complicity and the role of accomplices; connections of gambling organizers with state bodies; conspiracy measures; the nature and amount of profits from the gambling business.

Key words: gambling business, gambling, criminal offenses, evidence, interrogation, witness, suspect.

Вступ. Під час досудового розслідування злочинів, пов'язаних із зайняттям гральним бізнесом, обов'язково необхідно проводити таку слідчу (розшукову) дію, як допит, яку вчені тривалий час розробляють у вітчизняній криміналістичній літературі $[1 ; 2 ; 3]$.

Постановка завдання. Метою статті є розгляд питань тактико-криміналістичного забезпечення проведення допиту на початковому етапі розслідування кримінальних правопорушень, пов'язаних із зайняттям гральним бізнесом.

Результати дослідження. Допит кожної категорії осіб (свідків, підозрюваних) має свої особливості. Під час допиту доцільно застосовувати аудіо- та/або відеозапис.

У процесі цієї слідчої (розшукової) дії необхідно з'ясувати загальні відомості про:

1) особу допитуваного;

2) організацію, проведення та надання можливості доступу до азартних ігор;

3) азартні ігри;

4) співучасть у злочині;

5) інші злочини та правопорушення, пов'язані із гральним бізнесом.

Особливості предмета допиту залежать від виду азартної гри, місця її проведення, особи злочинця тощо.

Вивчення судово-слідчої практики дає підстави стверджувати, що під час допиту у справах про злочини, пов'язані з гральним бізнесом, необхідно з'ясувати: 
1) хто організував азартні ігри, проводив їх та надавав можливість доступу до азартних ігор;

2) які ігри було організовано та проведено;

3) місце вчинення злочину, чи організовано гральний бізнес в інших місцях;

4) учасники азартних ігор; яких саме

5) чи супроводжувався гральний бізнес вчиненням інших злочинів та правопорушень,

6) хто був співучасником грального бізнесу, яка форма співучасті, які функції та ролі виконував кожен співучасник, інші характерні ознаки співучасті (момент досягнення змови, стійкість, ієрархічність);

7) який період часу функціонує гральний бізнес;

8) чи мають організатори азартних ігор корумповані зв'язки в правоохоронних органах;

9) чи дотримуються організатори та особи, які надають доступ до азартних ігор, заходів конспірації та яких саме;

10) який порядок проведення азартної гри та роботи грального закладу;

11) хто є власником грального обладнання, на підставі чого його передано;

12) хто є власником місця, де організовано гральний бізнес, на яких підставах там працює організатор та його співучасники;

13) 3 якою метою організовано гральний бізнес;

14) чи отримано прибуток від грального бізнесу та який його розмір.

Підготовка до допиту в провадженнях за фактами злочинів, пов'язаних із зайняттям гральним бізнесом, має включати у себе:

а) ознайомлення з матеріалами кримінального провадження;

б) ознайомлення зі спеціальними питаннями надання послуг грального бізнесу;

в) отримання і вивчення інформації про особистість допитуваного;

г) складання письмового плану допиту;

г) визначення місця та часу проведення допиту;

д) залучення до участі в допиті спеціаліста, інших осіб [4, с. 241-242].

Допит підозрюваного разом з дослідженням вилученої комп'ютерної техніки відіграє ключову роль у розслідуванні злочинів, пов'язаних із зайняттям гральним бізнесом. Саме шляхом проведення допиту встановлюється більшість обставин, що підлягають доказуванню у кримінальному провадженні.

Під час допиту підозрюваного здебільшого виникають такі типові ситуації:

1) підозрюваний визнає свою вину та дає правдиві показання;

2) підозрюваний дає неправдиві показання та заперечує свою вину.

Показання осіб, які визнали себе винними у вчиненні злочину зазначеної категорії, слід ретельно перевірити оглядом комп'ютерної техніки, її аналізом, допитом інших осіб, проведенням судових експертиз та інших необхідних слідчих (розшукових) дій [5, с. 30].

Так, підсудний К. винуватість в інкримінованому йому злочині не визнав, заперечив свою причетність до організації грального бізнесу. Пояснив, що привіз вісім орендованих ним відеоатракціонів, щоб організувати розважальний заклад для проведення місцевою молоддю дозвілля виключно з благодійною метою. Для цього познайомився з місцевим жителем С., у якого винайняв приміщення. Згодом через відмову останнього здавати в оренду таке приміщення в тому ж будинку винайняв інше приміщення в Ч. У цьому приміщенні розмістив відеоатракціони, наглядати за якими попросив свою знайому В., до обов'язків якої належало прибирання та опалювання такого приміщення. Інших працівників, у тому числі операторів, на роботу не брав, будь 3 ким трудових договорів не укладав. Узагалі не мав на меті відкривати розважальний заклад до оформлення всіх дозвільних документів, тому клуб і не працював. Крім того, вказав, що вилучені в нього відеоатракціони не є гральними автоматами, оскільки суми виграшу не видають. Не може пояснити, чому потерпілі Л., Д., Ж. вказують на те, що неодноразово грали в його закладі на гральних автоматах в азартні ігри, а також те, що під час огляду місця події працівники податкової міліції вилучили сертифікати для гри на гральних автоматах, зошит із записами сум готівки, у якому міститься його підпис, а на місці адміністратора була Ш. [6].

У ситуації, коли підозрюваний чи обвинувачений не визнає вини, працівники поліції вважають за необхідне обов'язково:

1) допитати свідків та потерпілих $(23,3 \%)$;

2) провести одночасні допити підозрюваних та свідків з подальшим оголошенням показань, наданих зазначеними учасниками провадження на попередніх допитах (34,8\%); 
3) оглянути місце події (25,6\%);

4) призначити судові експертизи $(16,2 \%)$.

Головними джерелами доказів, які пред’являються допитуваним у такій категорії кримінальних проваджень, є: а) бухгалтерські, казначейські (банківські), планові, розпорядчі та інші документи, що підтверджують факти незаконного отримання доходу; б) протоколи допитів свідків і співучасників, які викривають особу у вчиненні злочину; в) висновки експертиз, якими підтверджуються зазначені факти; г) інші матеріали провадження [5, с. 30-31].

Під час розслідування злочинів, пов'язаних з наданням послуг грального бізнесу, широко використовуються покази свідків. Допит свідка є обов'язковою слідчою (розшуковою) дією у разі розслідування будь-яких видів злочинів. Метою цієї дії є одержання від осіб свідчень, що мають значення для кримінального провадження.

Допит свідка потрібно починати з роз'яснення допитуваному його прав, а також попередження про кримінальну відповідальність за відмову від дачі показань та за свідомо неправдиві свідчення. Якщо на цей момент у слідчого є сумніви в правдивості свідка, слід особливо підкреслити реальність відповідальності. Якщо такі підстави відсутні, то попередження про відповідальність доцільно робити обережно, роз'яснивши, що це лише обов'язок слідчого і він не означає, що свідка заздалегідь підозрюють у неправді [5, с. 31].

Свідками у провадженнях про злочини, пов'язані із зайняттям гральним бізнесом, можуть бути:

1) учасники азартних ігор;

2) особи, у яких організатори орендують приміщення для грального бізнесу;

3) обслуговуючий персонал грального закладу, який не бере участі в гральному бізнесі;

4) працівники правоохоронних органів;

5) судові експерти.

Під час допиту свідків мають місце такі типові ситуації: 1) свідок надає правдиві показання; 2) свідок надає неправдиві показання.

Так, наприклад, будучи попередженою про кримінальну відповідальність за дачу завідомо неправдивих показань за ст. 384 КК України та допитаною в судовому засіданні як свідок, П. показала, що на роботу до підсудного К. не наймалась, з ним не знайома і ніколи в залі гральних автоматів не працювала. Такий заклад узагалі не відкривався.

Під час досудового слідства П., також будучи попередженою про кримінальну відповідальність за дачу завідомо неправдивих показань за ст. 384 КК України, показала, що працювала в залі гральних автоматів, знала принцип їх роботи, вмикала такі пристрої для відвідувачів ключем-маніпулятором, брала гроші з клієнтів та видавала їм виграш готівкою.

Від цих показань у судовому засіданні відмовилась, не змігши пояснити причин їх зміни, які б заслуговували на увагу.

Показання, які дала суду П., визнані неправдивими, про що зазначено у вироку суду, та спростовані дослідженими судом доказами, у тому числі даними у суді показаннями потерпілих і свідків [6].

Надання свідком неправдивих показань зумовлене насамперед категорією допитуваних. Так, на допиті обслуговуючий персонал грального закладу, як правило, заперечує проведення грального бізнесу, оскільки працює в організаторів грального бізнесу, які приймали його на роботу та видавали заробітну плату.

3 метою протидії розслідуванню свідки відмовляються від дачі показань або ж дають неправдиві показання стосовно незаконного впливу на них правоохоронних органів.

Так, свідок М. відмовилась від показань, що дала на досудовому слідстві, мотивуючи це впливом на неї слідчого. Однак у суді вона не змогла пояснити, у який спосіб здійснювався цей вплив. Крім того, М. підтвердила, що протокол допиту особисто перечитувала та власноручно виконаним підписом підтвердила його правильність [6].

У такій ситуації необхідно допитати працівників правоохоронних органів, які виявили та проводили досудове розслідування цих злочинів, чи чинили вони будь-який тиск на свідків.

В окремих випадках виникає необхідність у допиті як свідка судового експерта. Так, допитаний у судовому засіданні судовий експерт В. роз'яснив, що вилучені в підсудного відеоатракціони є звичайними гральними автоматами, за винятком деяких змін у конструкції та програмному забезпеченні пристрою. Алгоритм гри аналогічний алгоритму гри на гральних автоматах. Такі пристрої виготовляють виключно спеціалізовані підприємства, а встановлені на них ігрові плати використовуються лише в гральних автоматах, на яких проводяться азартні ігри. 
Згідно з висновком комп’ютерно-технічної експертизи, всі вилучені гральні пристрої перебувають у справному стані, придатні для використання та відрізняються від гральних автоматів лише відсутністю у схемотехніці купюроприймача та купюроотримувача, а також емуляції в програмному забезпеченні використання одиниці часу замість аналога грошей [6].

Допит співробітників оперативних підрозділів дає змогу встановити обставини виявленого злочину, усвідомити зміст порушення законодавства. Допит зазначених осіб не представляє складності, тому що вони не зацікавлені в перекручуванні фактів і дають правдиві показання.

Під час допиту спеціалістів, які були присутні під час проведення огляду місця події, проводили експертне дослідження вилученої техніки. 3 питань встановлених ними фактів доцільно з'ясовувати питання технічного доступу до мережі Інтернет, способів поєднання між собою комп’ютерів тощо.

Допит спеціалістів у такому напрямі дуже потрібен, адже поряд з іншими доказами, зібраними під час розслідування кримінальної справи, такі свідчення є доказом умисних дій обвинувачених.

Цінні свідчення можуть бути отримані і від співробітників підприємства, які безпосередньо брали участь у наданні послуг грального бізнесу, зокрема, співробітників охорони, офіціантів та інших осіб. На підставі їхніх свідчень можна встановити становище на підприємстві, обставини здійснення конкретних операцій. Для одержання правдивих показань допит зазначеної категорії свідків необхідно проводити на ранній стадії розслідування, що дасть змогу уникнути тиску на свідків і значно знизить імовірність дачі неправдивих показань.

Одночасно слід мати на увазі, що нерідко працівники установи, виконуючи вказівки керівника, самі є втягнутими у злочинну діяльність [5, с. 31$]$.

У разі виявлення слідчим ознак впливу обвинуваченого на свідків, які є його підлеглими, необхідно вжити заходів щодо нейтралізації такої форми протидії розслідуванню.

Інша категорія свідків - члени сім’ї та знайомі обвинуваченого, його сусіди тощо. Їхні показання мають значення здебільшого для отримання даних, які характеризують особистість обвинуваченого. При цьому на достовірність їхніх свідчень значною мірою впливають особисті стосунки з обвинуваченим. У разі допиту членів сім'ї чи близьких родичів обвинуваченого обов'язково слід ознайомити допитуваного з положеннями ст. 63 Конституції України, оскільки недотримання цього правила може призвести до втрати доказового значення показань свідка.

Із зазначених вище особливостей допиту певних категорій свідків можна визначити типові мотиви надання ними неправдивих показань. При цьому доцільно розділити мотиви неправдивих свідчень у бік пом'якшення вини підозрюваного та, навпаки, у бік повної або часткової його обмови $[5$, с. 32].

Під час допиту свідків слідчий може застосовувати тактичні прийоми, а саме: роз'яснення допитуваному важливості його показань для встановлення істини; постановлення питань, що активізують у свідомості допитуваного асоціальні зв'язки; пред’явлення фотографій, схем, планів та інших об'єктів, що сприяють пригадуванню, у тому числі документів; ознайомлення допитуваного з фрагментами показань інших осіб; пред'явлення вилученої інформації, що зберігається в ЕОМ; пропозиція викласти факти, зберігаючи послідовність подій (пряму чи зворотну).

Застосування таких тактичних прийомів характерне тоді, коли під час допиту складається безконфліктна ситуація. Безконфліктна ситуація допиту, своєю чергою, не виключає тактичних проблем і не звільняє слідчого від активного управління процесом отримання необхідних свідчень від допитуваного.

У конфліктній ситуації, що складається на момент допиту, слідчий може застосувати такі тактичні прийоми, як: роз'яснення допитуваному значення щирого зізнання і давання правдивих свідчень; виявлення мотивів давання неправдивих показань й усунення цих мотивів; переконання 3 допомогою логічних аргументів у недоцільності спроб давання неправдивих свідчень; максимальна деталізація і конкретизація свідчень допитуваного; пред'явлення доказів, що викривають допитуваного (починаючи із самого важливого і навпаки); повторний допит.

Відповідно до ч. 9 ст. 224 КПК України слідчий, прокурор має право провести одночасний допит двох чи більше вже допитаних осіб для з'ясування причин розбіжностей у їхніх показаннях. На початку такого допиту встановлюється, чи знають викликані особи одна одну і в яких стосунках вони перебувають між собою. Свідки попереджаються про кримінальну відповідальність за відмову від давання показань і за давання завідомо неправдивих показань, а потерпілі за давання завідомо неправдивих показань.

Викликаним особам по черзі пропонується дати показання про ті обставини кримінального провадження, для з'ясування яких проводиться допит, після чого слідчим, прокурором можуть 
бути поставлені запитання. Особи, які беруть участь у допиті, їх захисники чи представники мають право ставити одна одній запитання, що стосуються предмета допиту.

Оголошення показань, наданих учасниками допиту на попередніх допитах, дозволяється лише після давання ними показань.

Цю слідчу (розшукову) дію слід проводити на початковому етапі розслідування, оскільки надалі можуть бути підготовлені неправдиві алібі, які досить складно буде спростувати.

Висновки. Таким чином, незважаючи на статус допитуваного, тип грального закладу та інші обставини, під час допиту свідків і підозрюваних з'ясовують: осіб, які організували азартні ігри, їх проводили та надавали можливість доступу до них; вид ігор, що було організовано та проведено; місце (місця) вчинення злочину; період злочинної діяльності; дані стосовно гравців; факт зв'язку грального бізнесу з учиненням інших злочинів та правопорушень; форму співучасті та роль співучасників; зв'язки організаторів азартних ігор з державними органами; заходи конспірації; характер і розмір прибутків від грального бізнесу.

Зважаючи на категорії свідків, розглядаються тактичні прийоми допиту: осіб з числа персоналу грального закладу, які не брали участь у гральному бізнесі (бухгалтерів, охоронців, барменів, водіїв, прибиральників); працівників суб'єктів господарювання (підприємців), які мали відношення до грального закладу (орендодавців, електриків, сантехніків, програмістів тощо); працівників органів місцевої влади та правоохоронних органів, які проводили перевірки в порядку реагування на звернення за фактом зайняття гральним бізнесом; учасників азартних ігор (гравців) та інших осіб, які перебувають 3 ними в певних стосунках (сусідів, членів сім’ї, знайомих); громадян, які проживають чи працюють поряд з гральним закладом. Під час їх допиту застосовуються такі тактичні прийоми: використання суперечностей між показаннями свідка та іншими доказами, у тому числі пред’явлення речових доказів $(65,0 \%)$; роз'яснення реальності притягнення свідка до кримінальної відповідальності (46,0\%); використання суперечностей у показаннях $(27,0 \%)$; використання чинника раптовості $(18,0 \%)$; стимулювання позитивних якостей особи $(11,0 \%)$. Особливою категорією допитуваних $є$ спеціалісти різного профілю, які надають фахові консультації, пояснюють специфіку проведення азартних ігор.

Конфліктні ситуації допиту підозрюваних пов’язані насамперед з тим, що допитуваний не визнає своєї причетності до організації, проведення та надання можливості доступу до азартних ігор $(29,6 \%)$. При цьому він наполягає на тому, що не усвідомлював злочинного характеру своїх дій $(10,4 \%)$; перекладає вину на інших співучасників злочину, зокрема організаторів азартних ігор (19,2\%); дає неправдиві (суперечливі) показання $(21,0 \%)$. Найефективнішим прийомом 3'ясування розбіжностей у показаннях таких допитуваних, на думку $34,8 \%$ респондентів, є одночасний допит підозрюваних і свідків 3 подальшим оголошенням показань, наданих ними на попередніх допитах.

\section{Список використаних джерел:}

1. Бахин В.П. Допрос : лекция. Киев, 1999. 40 с.

2. Бахін В.П., Весельський В.К. Тактика допиту : навчальний посібник. Київ, 1997. 75 с.

3. Коновалова В.Е. Допрос: тактика и психология : учебное пособие. Харьков : Консул, 1999. $157 \mathrm{c}$.

4. Пиняга Р.О. Особливості проведення допиту підозрюваного під час розслідування злочинів, пов'язаних із зайняттям гральним бізнесом. Реформування системи кримінальної юстиції в Украӥні: кримінально-правові, кримінально-процесуальні та криміналістичні проблеми: зб. матеріалів міжнар. наук.-практ. конф. Ірпінь : Ірпінська фінансово-юридична академія, 2012. C. 241-242.

5. Виявлення, документування та розслідування злочинів, пов'язаних з наданням послуг грального бізнесу : методичні рекомендації. / В.В. Топчій, А.В. Савченко, О.Ю. Татаров та ін. Київ : Нац. акад. внутр. справ, 2011.36 с.

6. Вирок Камінь-Каширського районного суду Волинської області. Кримінальна справа № 0304/557/12. Сдиний державний реєстр судових рімень. URL: http://www.reyestr.court.gov.ua/ Review/24384136. 